\title{
The implementation of good corporate governance at Baitut Tamwil Muhammadiyah (BTM) Tegal
}

\author{
Arip Hidayat
}

Koperasi LKMS BTM Artha Surya, Indonesia

\begin{abstract}
Purpose - Author studied the implementation of good corporate governance in a context of microfinance institution. Corporate Governance is a very strategic determining factor for the progress of a company in order to continuously increase value and maintain an ongoing and sustainable growth process.

Method - Sources of data used in this study were taken from primary data and secondary data. Apart from interviews, other primary data source categories include reviewing, reading several global financial reports and standard operating procedure (SOP). Secondary data were obtained from books as a complement to primary data sources. Additional secondary data source of this research was obtained by conducting literature reviews.
\end{abstract}

Result - Modern pondok of Tazakka uses at least six different waqf program as a financial source of their activities. These programmes are asset waqf, cash waqf, productive waqf, benefits waqf, profession waqf, and transfer of rights waqf. The programmes help the pondok to be more autonomous and able to provide various benefits for the scholars of the pondok and the people surround it.

Implication - The results show that the Baitut Tamwil Muhammadiyah (BTM) implemented a good corporate governance.

Originality - This study has enriched an empirical study of corporate governance in microfinance institution in Indonesia.

Keywords: corporate governance, microfinance institution management, baitut tamwil, cooperative 


\section{Introduction}

Implementation of Good Corporate Governance is greatly strategic to determine factors for a company's development to continuously increase its value and maintain its ongoing and sustainable growth processes. Every company is obliged to continuously work hard to obtain benefits from the implementation of Good Corporate Governance by examining the concept of Good Corporate Governance performed by the developed countries since 1980. The warming corporate governance issues since then was in line with the needs of the economic system in response to the bankruptcies of several top companies (Wibowo, 2010). With the concept of Good corporate governance, it is a part of humans' endeavors so that every company runs well and produces the best results.

Everyone hopes that their business will run well. Each group of investors also hopes that their investment will produce the best with healthy finance, and management, so that the company will reap the public's trust. Regarding to how expensive a belief is, there was a case where the management of Baitut Tamwil Muhammadiyah (known as BTM) in Brebes Regency prohibited its manager from submitting the financing to the Central Java BTM center to fulfill its liquidity in May 2019 or in Ramadan $1440 \mathrm{H}$. This prohibition was issued due to the increasing factor of Non Performing Financing (NPF) in BTM has reached two digits.

It seems that the non-performing loans at BTM Brebes have made some successors reluctant to signing the financing applications. When communicated by the manager to the central management of Central Java BTM, the answers explained that the Non Performing Loans (NPF) is a risk for every financial institution including BTM. Therefore, every financial institution does not have to run from the risk but should manage the existing risks not to become a time bomb destroying the financial business services in the related institutions. At least, the NPF value of $5 \%$ set by Bank Indonesia for the financial institutions is a measure for every financial institution to always maintain its minimum NPF value (Regulation of Central Bank of Indonesia).

Once again, every financial institution needs to manage its business risks properly to minimize the possible loan problems. The 
management illustration above teaches us that a company will gain the trust from the public when the campany is well managed and looks healthy in both finance and management.

Healthy finance and management are two absolute requirements for the success of BTM. So, when BTM wants to be financially healthy, for example, it must be able to manage its potential risks by identifying, measuring, monitoring and controlling risks arising from all existing business activities at BTM (Regulation of Central Bank of Indonesia No.13/23/PBI/2011). The risk control pattern is in the field belonging to the financing committee board consisting of leadership elements from the BTM policy makers. Even so, when BTM wants its employee performance mechanism to run in orderly, maximally and efficiently, the policy makers at BTM must issue the related regulations. Thus, the employee performance mechanism clearly has its own operational rules and standards.

It is necessary to understand that Baitut Tamwil Muhammadiyah (BTM) as a Sharia microfinance institution is a new phenomenon in Indonesia with its distinctive features since belonging to a religious organization, namely Muhammadiyah organization engaged in economy. The other unique reason is that, from the operational side, even though BTM is similar to batul maal wa tamwil (BMT), BTM firmly chooses a special path which is profit oriented, and leaves maal management to amil zakat, infaq, and shadaqah to Muhammadiyah (Lazismu) institutions.

In the government, BTM is institutionally included into the field of Sharia cooperatives. Sharia cooperative is a form of non-bank financial industry which has continuously experienced a rapid growth. The data in 2018 showed that the number of KSPPS units belonging to the Sharia cooperatives has already reached 2,253 units $(1.5 \%$ of the number of cooperative business units), not including the Sharia cooperatives included in the Sharia microfinance institution (LKMS) units under the supervision of the financial services authority (OJK), so that the growth of Islamic cooperatives as an industrial infantry is quite impressive. This number is expected to continuously grow as the sharia-based financial industry develops (Fidiana, 2017).

BTM with all its uniqueness deserves to be the research object. Only few studies have discussed the BTM. Therefore, the 
researchers have considered BTM in Tegal Regency as the research object.

The presence of Islamic microfinance institution of Artha Surya Baitut Tamwil Muhammadiyah Cooperative in Tegal Regency JIEMB | 26 (known as Koperasi LKMS BTM), as a Sharia microfinance business institution in Tegal Regency has participated especially in enlivening the treasures of Sharia cooperatives in Tegal Regency and deserved appreciation. Yet, its business development needs to be well aware. So that the Sharia microfinance business has positive impacts without resulting in destructions.

Several factors should be well supervised for the security of Sharia microfinance business in the BTM of Tegal Regency. First, in its operational activities, BTM has not yet been guaranteed by the deposit insurance agency (known as LPS/Lembaga Penjamin Simpanan). Thus, BTM has a fairly large risk, especially in terms of financing distribution. Even in the process of analyzing the prospective customers, BTM in Tegal Regency has not used the BI Cheking application. In distributing its financing, the BTM in Tegal Regency has used a murabahah contract based on a profit margin and a mudharabah contract with a profit sharing. The distributed products used two contracts equally vulnerable to the occuring risks (Yulianti, Bustami, Atiqoh, \& Anjellah, 2018).

Second, the annual business data calculation for the BTM in Tegal Regency has reached the assets of IDR 15.2 billion with the capital of IDR 1.5 billion, the out standing of only IDR 9.4 billion, and Non Performing loans (NPL) of up to $30 \%$ that this certainly cannot be said to be balanced. Third, the BTM in Tegal Regency with the financing products, such as buying and selling on motor vehicles, financing business capital, and others using four types of contracts: murabahah, mudharabah, ijarah, and qard. The details of murabahah receivables of IDR $5,286,584,159$, multi-service ijarah receivables of IDR. 2,692,823,176, and ijarah receivables: IDR 10.500.00. The data show that the murabahah contract was greatly dominant, and still has to be traced to the truth. Was it natural or vice versa? On the other hand, the imbalance in business processes above is in the contrary.

The supervision to the Sharia financial-service business of the BTM institutions in Tegal Regency was extremely tight since officially under the supervision of the financial services authority 
(known as OJK/Otoritas Jasa Keuangan). Each supervision, mentoring, and coaching from the OJK was tighter when compared to that of the ministry of cooperatives. The process of legal-formal transactions with customers was performed to a variety of product contracts from the official umbrella of the National Sharia Council (DSN-MUI). The DSN-MUI fatwas have clearly and firmly provided rules for each process of contract form to make the business run well.

One example of fatwa (DSN-MUI) No. 04/IV/2000 on murabahah has mentioned that there are regulations with the aim of preventing the risk of loss of murabahah financing from the related institutions. The points have included that the bank must convey all matters related to the purchases, for example, if the purchase is made in debt. The client should submit a request and promise to purchase an item or asset to the bank. If the bank accepts the request, he must first purchase the asset that he legally ordered the merchant (DSN-MUI No. 04/IV/2000). But in fact, a lot of financing in BTM is involved in bad credit. Muhammad Syaifullah and Endang (2018) agreed that the financing procedure was good. They have published their research results related to the analysis on murabahah financing and mentioned that a good murabahah financing management procedure involves customers including; customer application, customer data verification, financing analysis, committee submission, approval, contract and guarantee agreement, disbursement, and monitoring.

Third, the BTM in Tegal Regency, as a Muhammadiyah-owned charity, is certainly demanded to be more credible. This is because Muhammadiyah has a long history in fighting for the presence of an interest-free credible financial institution, through tarjih The assembly congress in Sidoarjo in 1968, the tarjih assembly congress in Wiradesa in 1972, the tarjih assembly congress in Garut in 1976, and the tarjih assembly congress in Malang in 1989 have also initiated and recommended that Moslems in general and Muhammadiyah members in particular, through the leadership of Muhammadiyah center, seek the realization of an economic system concept, especially related to the banking institutions in accordance with the Islamic principles (Muhammadiyah, 2018).

Any decision based on the figh of muhammadiyah summarized in a set of decision book on tarjih muhammadiyah (HPT) vol 3 , Chapter III on Bank Interest, in which one of eight decision points is Journal of Islamic Economics, Management, and Business-Vol 2. No.1 (2020 
that Islamic economy is one economic system based on the Sharia values in the form of justice, honesty, interest-free, and commitment to improve the mutual welfare (Muhammadiyah, 2018). In fact, there is a gap between the strictness of rules and the results which are still far from expectations. The question arises regarding to the good corporate governance of BTM in Tegal Regency. Has the corporate governance of BTM in Tegal Regency well implemented? To what extent are these governance rules applied and evaluated? These questions have inspired the researchers to conduct a further study.

As explained above, a good company is a company which is good in both finance and management resulted from the good governance of all managers, especially the leaders who have made the policies. Therefore, to investigate this issue, the theory of GCG is greatly necessary as an instrument for analysis.

Good corporate governance in Indonesia has become popular since 1997, when the economic crisis hit Indonesia. It is difficult to deny that, during the last ten years, the term of Good Corporate Governance (GCG) has increasingly become more popular and is placed in an honor position. First, GCG is one of the keys to the success of a company to grow and make profits for a long term, as well as win the global business competitions. Second, the economic crisis in Asia and Latin America is believed to have its emergence due to the failure in implementing the GCG.

According to experts, GCG is defined a good organizational governance mechanism in managing the organizational resources efficiently, effectively, economically or productively with the principles of openness, accountability, responsibility, independence and fairness in order to achieve the organizational goals. In theory, Good Corporate Governance (GCG) is a concept/an understanding which can ultimately create a system regulating and controling a company/organization in creating the value added for all stakeholders. Good Corporate Governance (GCG) not only ensures that the management runs well, but also hopes to ensure that the management process runs efficiently.

Based on the backgrounds above, the research problems are formulated as follows:

1. How Good Corporate Governance is implemented by the BTM in Tegal Regency? 
2. To what extent is the theoritical values of Good Corporate Governance implemented in the financial management and organizational decision making of BTM in Tegal Regency?

\section{Literature review}

\section{Good corporate governance}

In language, Good corporate governance means the principles underlying a company management process and mechanism based on laws and regulations and business ethics. The implementation of GCG principles can improve the company performance and longterm economic value for investors and stakeholders.

In theory, Good Corporate Governance (GCG) is a concept/an understanding which can ultimately create a system regulating and controling the company/organization in creating the added value for all stakeholders. Good Corporate Governance (GCG) can certainly ensure the management run well, but the management should not be easily satisfied just by ensuring the management process run efficiently.

Corporate governance is developed based on two main theories, namely stewardship and agency theory. Stewardship theory is developed based on the philosophical assumptions related to the human nature in which humans are intrinsically trustworthy, able to act responsibly, and have the integrity and honesty with others.

The Good Corporate Governance in Islam refers to Al-Quran and $\mathrm{Al}$-Hadith which makes it unique and different from the concept of Good Corporate Governance in the western world view. In Islamic view, corporate governance must integrate the regulatory aspects based on the context of discussing the corporate governance in Islamic financial institutions and several relevant Islamic ethical principles including prohibition of usury, maysir and gharar, implementation of ethical life behaviors by upholding decency, justice, active in seeking knowledge, diligent, competent in the related fields, upholding the stakeholders' interests, fair competition, openness, confidentiality, as well as respect and fair wage (Hasan, 2012). 


\section{The urgency of good corporate governance implemented by the}

\section{BMT/BTM}

$B M T$ as a Sharia financial institution closely serving people's interestsis required to become an example to implement the Good Corporate Governance optimally added with the spiritual concept. $B M T$ 's spiritual concept is anything related to the Sharia aspects in both product and business ethics which are expected to improve the employee performance and public confidence.

People's assumption that $B M T$ is similar to the ordinary saving and loan cooperatives in different uniforms, will slowly erode if BMT has well implemented the Good Corporate Governance equipped with its spiritual aspects. Thus, there are two steps proposed by the researchers to perform immediately, namely BTM external audit () and BTM's internal assurance.

\section{Methodology}

This research is a descriptive qualitative research. The approach method used in this study is an empirical sociological approach. That is research to find the truth based on social facts or social reality, starting from observation, in-depth interviews, document studies and then connected with empirical facts in the field so as to get a conclusion or answer to the problems studied.

The location of this research is at the LKMS Baitut Tamwil Muhammadiyah (BTM) cooperative office, Artha Surya, Tegal district. Data collection was carried out in several ways, namely observation and direct interviews. After the data from the field is collected with the data collection method described above, the writer will manage and analyze the data using descriptive analysis.

\section{Results and discussion}

\section{Profile of BTM Artha Surya, in Tegal Regency}

The profile and history of the existing BTM Artha Surya, in Tegal Regency cannot be separated from the history of its initial establishment 22 years ago. This was expressed in the author's interview with Mr. Ali Firdaus.

"Good corporate governance was early implemented by $B T M$. BMT was migrated to $B T M$ and began trying to implement 
a good governance. The BMT which was migrated to BTM continued to work with one central management at the Central Java BTM center originally to well manage the BTM".

The Baitul Mal Wat Tamwil Artha Surya was inaugurated on February 15, 1998 by the Muhammadiyah Regional Leaders of Tegal Regency, $\mathrm{H}$. Fathi Rozak. The idea in forming the BMT began at the Muhammdiyah Regional Conference through its Economic Council to establish a Sharia Public Financing Bank (known as BPRS/Bank Pembiayaan Rakyat Syariah). However, because the capital to establish a BPRS was very large, the PDM finally decided to establish a BTM. Artha Surya's name consists of two words: Artha and Surya. Arta was taken from Javanese language which means money, while Surya means sun as the symbol of Muhammadiyah.

Artha Surya BMT officially began operating on February 16 , 1998 with the initial capital of thirty million rupiahs $(30,000,000.00)$. This capital was obtained from the treasury of Muhammadiyah Regional Leadership of approximately twenty million rupiahs $(20,000,000.00)$ and the remaining capital was obtained from the participations of benefactors of ten million rupiahs $(10,000,000.00)$.

BMT ARTHA SURYA, which has now changed into the Baitut Tanwil Muhammadiyah (BTM) Artha Surya (in accordance with the decision made by the Muhammadiyah Central Leadership) which is now in its $22^{\text {nd }}$ anniversary. Starting from a small place, using the complex of Aisyah Banjaran Kindergarten (now becoming BUDI MULIA Islamic Integrated Primary School), then developed its own place in the complex of Banjaran Permai market, and $\backslash$ rapidly developed into BTM ARTHA SURYA located on the south highway Banjaran No. 15, Adiwerna. Then the head office was then established on the south highway Banjaran No. 57 followed with Adiwerna branch, Tarub Branch, Jatinegara Branch, Margasari Branch, and Balapulang Branch located in Tegal Regency with a total asset of IDR 17,000,000,000.

Baitut Tanwil comes from a combination of two meanings. Bait means house, while tanwil (developer of assets), originally from the word maal means asset. Artha Surya also consists of two words: Artha and Surya. Artha was taken from the Javanese language means money, while surya means sun as the symbol of Muhammadiyah. 


\section{Implementation of GCG}

After the researchers have collected the data from interviews, observations, and documentation, it is concluded that the BTM in Tegal Regency has generally implemented the values of Good

JIEMB | 32 Corporate Governance, such as transparency, accountability, responsibility, independence and fairness.

However, after conducting a further analysis based on the data collected by the researcher, there values of Good corporate gevernance that still poorly implemented or in other words, it was still in the implementation process stage.

As previously stated, Good Corporate Governance is ideally a good organizational governance mechanism in managing the organizational resources efficiently, effectively, economically, and productively with the principles of openness, accountability, responsibility, independence and fairness to achieve the organizational goals. Good organizational governance can be seen from the context of both organization's internal and external mechanisms.

The organizational internal mechanism focused more on how the leadership of an organization regulates the organizational operation in accordance with the above principles. Meanwhile, the external mechanism emphasizes more on how the organizational interactions with the external parties run in harmony without neglecting the organizational goals.

\section{Analysis on Good Corporate Governance implemented by the BTM Artha Surya in Tegal regency}

The advance theory has abundantly described the GCG, and in general, the analysis on the main principles of good corporate governance was implemented by the LKMS BTM Artha Surya in Tegal Regency as follows:

1. Transparency

Transparency is the openness in conveying materials and relevant information as well as the decision making process. In this case, the BTM discloses information and information that must be true and in accordance with the reality without lies and frauds to its members or the other stakeholders.

From the results obtained from the researchers' interview with the head of BTM board, $\mathrm{H}$. Kholidin, it was explained that the 
concept of transparency or openness was seen from the recruitment process for BTM employees which mechanisms included the candidates proposed by the Managers to the management based on those passing the administrative selection must be completed by the prospective BTM employees: copy of the latest and legalized diploma, passport-size photographs of $3 \times 4$, curriculum vitae, copy of Recidential Identity Card, copy of Muhammadiyah membership card (KTM), branch leadership cover letter of, and local Muhammadiyah branch.

The prospective employees were then selected by the management through written tests and interviews covering the test materials on Economics, Management, al-Islam and Muhammadiyah knowledge. The final result was determined by the management added with the inputs given by the managers for consideration.

In terms of recruitment, the BTM in Tegal Regecy, opens the employee recruitment vacancies to public. However, in the process, it involves the local branch (Muhammadiyah Branch Leadership) to control and provide recommendations for each prospective employee as a Muhammadiyah organization cadre. In fact, this is a part of exclusivity belonging to the BTM administrators in recruiting the prospective employees that Muhammadiyah cadres can play their role in developing the business charities. However, , the professionalism elements have become the main benchmark in several fields and parts.

\section{Accountability}

Accountability is the clarity of functions and implementation of responsibility of the BTM organs to run the management effectively. For example, the Funding officer (FO) function, one of the marketing functions, specifically focused on raising the capital from the third parties either in savings or deposits. The BTM in Tegal Regency has implemented the principle of accountability which is generally in accordance with their respective job descriptions, as expressed by the manager of BTM Margasari Branch, Ahmadi, stating that the implementation of Good Corporate Governance related to the decision making at the Margasari branch office on financing is based on personal or closeness. On the basis of decision making, there must be an agreement from the committee board and also take into account the survey results from the surveyor. So, the submission is 
not only based on the deemed feasibility to directly approve the proposal.

The interview results above explained that the functions of the committee board and surveyors in processing and analyzing the

JIEMB | 34 feasibility of a prospective customer were in accordance with the regulations. It also described the clarity of function of the BTM internal parts or organs was in accordance with their respective job descriptions. Although there are several sections in those three branch offices (Jatinegara, Margasari, Balapulang) with job descriptions which seem overlapping, such as the roles of account officer and funding officer.

As explained by Sugino, the Manager of BTM Balapulang branch, several sections in the BTM Branch, such as the Marketing section which has double job descriptions since the branch head at one time must also be able to play his/her role as a part of the financing section if a customer comes to the office, while the financing staff is taking a break.

This not only happens in BTM Balapulang branch which employees have double functions and jobs. This is especially true in branches with four employees only. His main job is in the landing (AO) and Funding (FO) sections. According to the researchers' observations, this occured due to the number of assets which were still small and automatically managed by few employees. So the existence of multiple jobs in certain BTM branch offices does not mean that they have unclear, but effective and efficient functions.

\section{Responsibility}

Responsibility is the conformity of BTM management with the applicable laws and regulations and the principles of well managing the financial institutions. Based on the accountability principle, the BTM in Tegal Regency is related to the members that the BTM's cash activities and daily financial circulation management are in accordance with the applicable regulations. The daily report indicator is running well and on time. Hari Bagus Setiawan explained that the reports were in accordance with the procedures and on time Since the reports were daily sent by the branch offices. A report was once sent a little bit late, due to the power failure.

Due to the researchers' observations, the accountability aspect is related to the management appropriateness with the applicable regulations either daily, monthly, or annually. Although 
some errors were found when calculating the difference, but those rarely happened. However, some main rules related to the Sharia aspects, the BTM in Tegal Regency has not fully complied with the existing regulations, as explained in the interview with the head of BTM management: " BTM has not complied with the OJK and DSN regulations, yet still in process. There are still many marketing and financing techniques not yet ideal as the DSN fatwa.

He also stated that BTM has not fully complied with the OJK and $D S N$ regulations. It can be seen from the patterns of product introduction applications, contracts, and contract executions to customers presumed having no education or perhaps lack of effectiveness in education related to the Sharia values to the prospective customers. He further mentioned the existence of several BTM managers explaining the results' certainty percentage at the beginning. An example of a guaranteed profit sharing from a time deposit is for example $0.8 \%$ per month. The diction used in the Sharia system was to explain the term "ER" (Equivalent Rate) which means interest equivalent. The ER value was obtained from the business results from the previous month.

\section{Independence}

Independence is related to BTM's behavior and action objectively and freely from any influence/pressure from any party. To find out the BTM's independence aspects, see the results of the following interviews. The BTM has not been freed from the intervention of the other parties since that from the center was also not yet independent, for example regarding to the rules, such as the BTM's primary mandatory to borrowthe capital credit from the center. When the regional leaders were in need, they were sometimes directed to the BTM. Although on the other hand, the PDM was the owner, there must be coordination first, as the rules apply.

The aforementioned explanations illustrate that BTM as a Sharia financial institution in Tegal Regency was not yet fully independent because intervention were still given by the outside parties regarding to several policies. First, the unwritten "appeal" from the Central Java BTM which requires each Primary/Regional BTM must borrow funds from the center. According to the researchers, the Central Java BTM Center started gaining the 
minimal profits for its operational activities, such as visiting several regions.

Second, as explained by the Head of BTM Management, intervention can also be seen from the attitude of some regional

JIEMB | 36 leaders who place the administrators without any coordination with the existing management ranks. Since management is the most important element in a microfinance institution, the management must have a regulation.

It is important to formulate the business or management policies. According to him, it is better if the new candidates for the new management can replace the old to coordinate the existing board members.

\section{Fairness}

Fairness is a form of fairness and equality to influence the rights of stakeholders based on agreements and laws in force. Does BTM always give its members' rights?. Fairness principle does not differentiate the employees from the others, having healthy cooperation and mutual motivation. Based on the interviews conducted by the researchers, the BMT in Tegal Regency has obeyed the fairness principle as an indicator that the BTM has given its members' rights, including decent salary and good working support facilities, such as vehicles and uniforms.

Hari Bagus setiawan has explained thatBTM Artha Surya in Tegal Regency has given the prosperity for its employees, for example the annually increasing salary, facilitated with the inventory vehicles, uniforms, etc. He also stated that BTM has striven to fulfill its employees' rights. Ahmadi further explained that BTM has given the properity to its employees (especially for those living in Margasari). According to him, the prosperity was given depending on the assessments given to the employees.

However, the reasonableness aspect was not yet been well fulfilled due to the involvement of employees as the stakeholders, for example, in formulating the profit sharing targets. This policy is still purely in the management's hands inputs from the head office as a consideration. Ali Firdaus explained that the details of BTM employees as a part of stakeholders have not been involved in determining the profit sharing ratio, but in general they were involved in providing the Business and Budget Plan inputs for the planning years. 


\section{Conclusion}

Based on the research results regarding to the Good Corporate Governance implemented by the BTM in Tegal Regency, it can be concluded that the implementation and mechanism of Good Corporate Governance (GCG) is already in the process stage, such as the implementation of transparency, accountability, independence, responsibility and fairness processes.

The Good Corporate Governance (GCG) concept is not yet fully implemented by the BTM, including accountability or clarity of functions. There are some employees with multiple jobs, such as the marketing employees at the same funding time. Of course, when referring to the management science, this is not very good condition due to the overlapping jobs. After analyzing this existing case was caused by the BTM's way in adjusting the number of employees with that of the existing assets.

\section{References}

Fidiana, F. (2017). Tinjauan Kritis Kesyariahan Koperasi Syariah. IQTISHADIA: Jurnal Ekonomi dan Perbankan Syariah, 4(2), 137-154.

Hasan, Z. (2012). Shari'ah Governance in Islamic banks. Edinburgh University Press.

Himpunan Putusan Tarjih Muhammadiyah Jilid 3, 2018. Yogyakarta : Suara Muhammadiyah hal 203

Wibowo, E. (2012). Implementasi Good Corporate Governance di Indonesia. Jurnal ekonomi dan Kewirausahaan, 10(2).

Yulianti, R. T., Bustami, A., Atiqoh, N., \& Anjellah, R. (2018). Studi Komparasi Penerapan Manajemen Risiko Produk Pembiayaan di Lembaga Keuangan Mikro Syariah. JURNAL SYARIKAH: JURNAL EKONOMI ISLAM, 4(1). 
Arip Hidayat

JIEMB | 38

Journal of Islamic Economics, Management, and Business-Vol 2. No.2 (2020) 